\title{
A new ostracod (Crustacea) species (Geffenina wangi) from the Middle Permian of Jebel Gharif (Central Oman)
}

\author{
SYLVIE CRASQUIN-SOLEAU
}

CNRS, FR 32, Université Pierre et Marie Curie, Département de Géologie Sédimentaire, T.46-56, E.5, case 104, 75252 Paris cedex 05, France

\begin{abstract}
This paper describes Geffenina wangi a new species of ostracod and lists associated ostracod species discovered in the Khuff Formation, Middle Permian (Wordian) in the Jebel Gharif area (Central Oman). J. Micropalaeontol. 22(1): 101-105, July 2003.
\end{abstract}

\section{INTRODUCTION}

The area studied is located on the south-western border of the uplifted Haushi-Huqf Massif in the Central Oman (Fig. 1). The succession spans the Artinskian? to Wordian stages of the Middle Permian (Broutin et al., 1995; Angiolini et al., 1998). It includes the fluvial to tidal sandstones and mudrocks of the Gharif Formation, conformably overlain by the marine marlstones and bioclastic limestones of the Khuff Formation. In the Jebel Gharif area, the Khuff Formation is disconformably capped by the Lower Cretaceous Jurf and Qishn Formations (Fig. 2). The Jebel Gharif section (located at $19^{\circ} 57^{\prime} 01^{\prime \prime} \mathrm{N}-$ $\left.57^{\circ} 21^{\prime} 38^{\prime \prime} \mathrm{E}\right)$ has been described by Angiolini et al. (2003). The Khuff Formation, assigned to the Wordian on the basis of brachiopods and conodonts (Angiolini et al., 1998; Angiolini \& Bucher, 1999), has been subdivided into three members, as in other areas of the Haushi-Huqf Massif (Angiolini et al., 2003). The base of the Formation has been placed at the bottom of the bioclastic sandstones with wave-ripples (Unit C on Fig. 2; Angiolini et al., 2003), sharply followed by bioclastic limestones with encrusting bryozoans (Unit D on Fig. 2). Units C and D form the Member 1 which is thin and consists of coarser-grained sandy and bioclastic limestones interbedded with nodular limestones. Coarser-grained bioclastic sandstones with wave-ripples are still abundant in Member 2. The base of Member 3 is marked by bio-intraclastic sandstone beds with large intraclasts. It is composed of brachiopod-rich biocalcirudites interbedded with marly limestones and marlstones.

The ten samples studied contained ostracods extracted from the sediments by hot acetolysis (Lethiers \& Crasquin-Soleau, 1988). The ostracod fauna is composed of about 700 specimens belonging to 17 species and 10 genera (Table 1). Almost all the species found here were also present in the northern cliff of the Haushi-Huqf massif (Crasquin-Soleau et al., 1999) (see Fig. 1). One species is new: Geffenina wangi Crasquin-Soleau n.sp.

\section{SYSTEMATIC DESCRIPTION}

$\mathrm{RV}$ : right valve; LV: left valve.

Order Palaeocopida Henningsmoen, 1953

Suborder Kloedenellocopina Scott, 1961 emend. Lethiers, 1978 Superfamily Kloedenellacea Ulrich \& Bassler, 1908

Family Beyrichiopsidae Henningmoen, 1953

Genus Geffenina Coryell \& Sohn, 1938

Geffenina wangi Crasquin-Soleau n.sp.

(P1. 1, figs 1-6)
Derivation of name. Dedicated to Dr. Wang Shang-qi, Nanking Institute of Geology and Paleontology Academia Sinica, Popular Republic of China.

Diagnosis. Species of genus Geffenina with pitted and reticulated surface.

Holotype. One complete carapace figured Pl. 1, fig. 1; collection number P6M1438.

Paratypes. One complete carapace figured Pl. 1, fig. 4; collection number P6M1435.

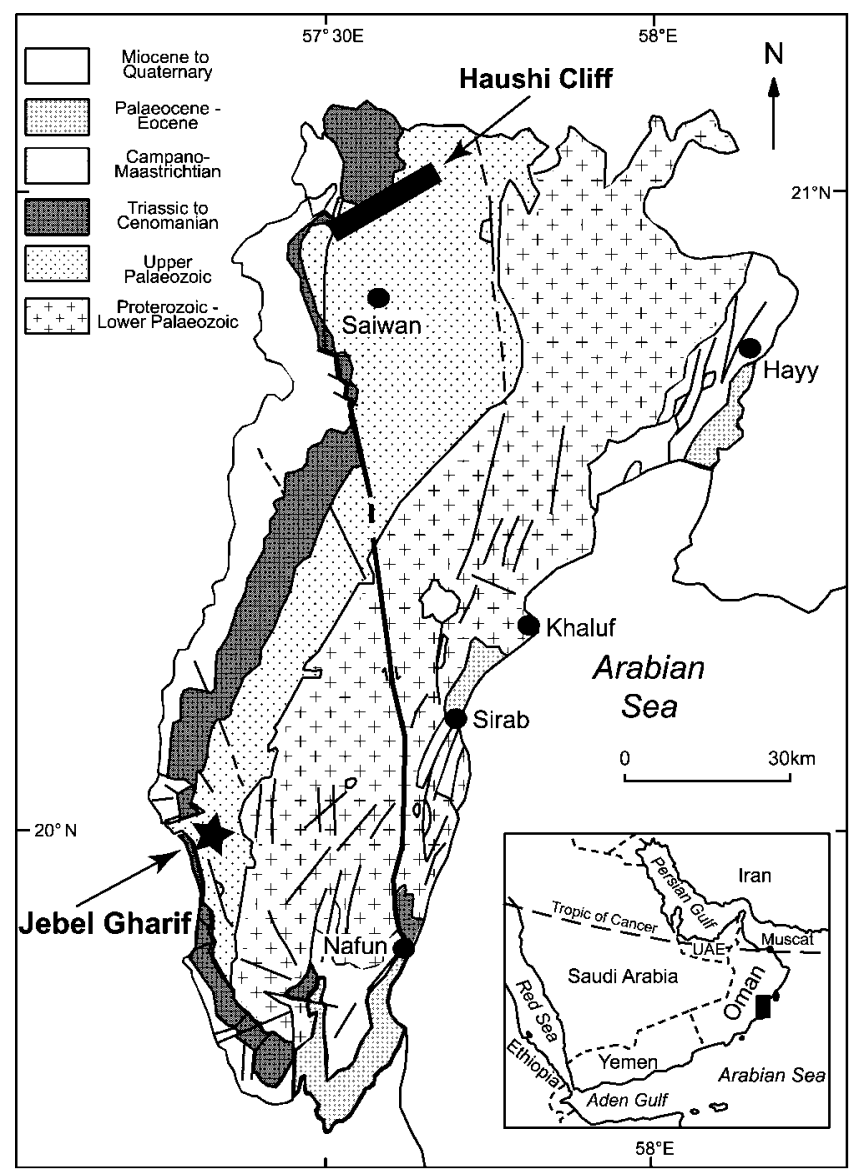

Fig. 1. Location map of the area studied (modified after Platel et al., 1994). 


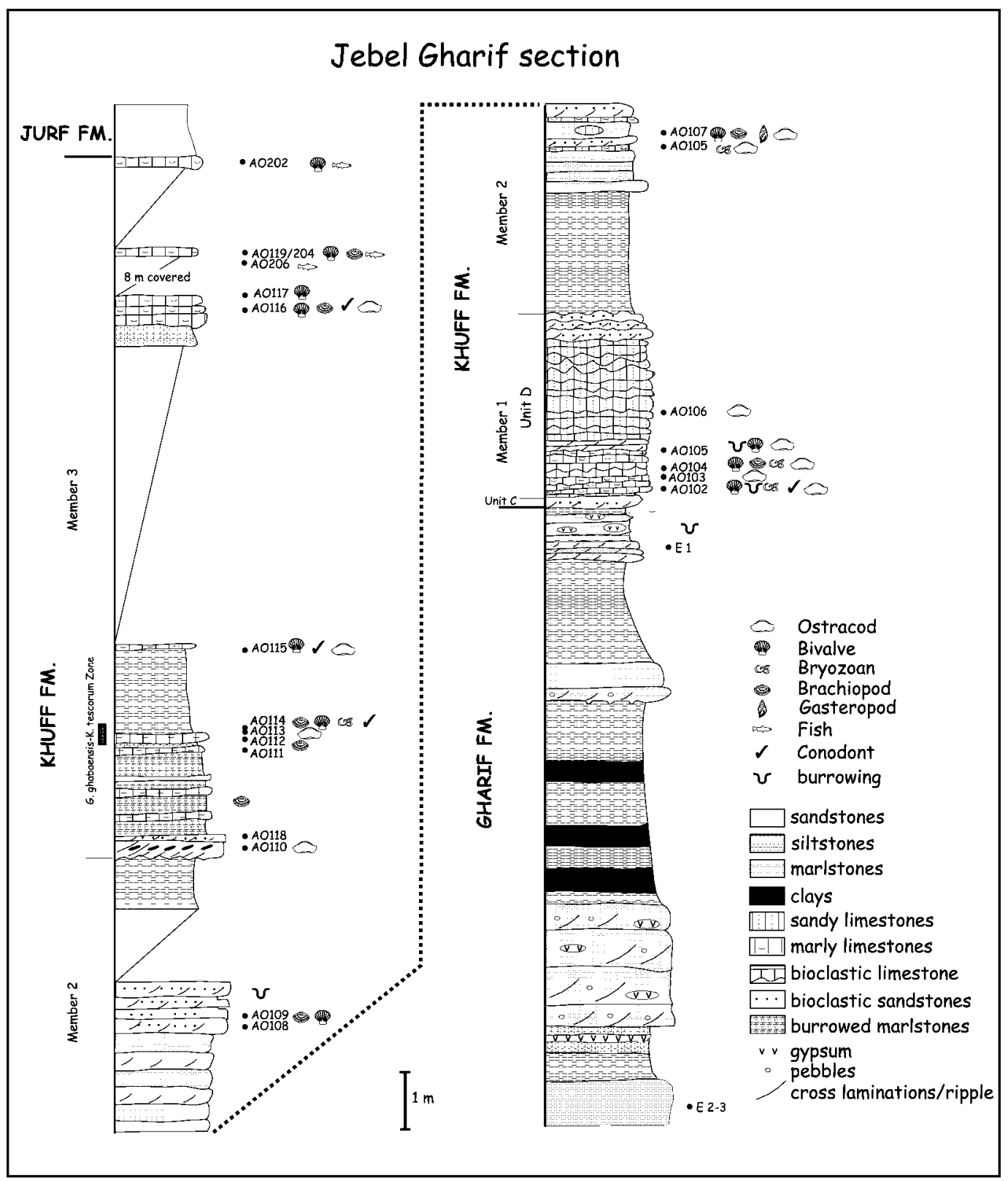

Fig. 2. Stratigraphic section of the Khuff Formation in Jebel Gharif area (modified after Angiolini et al., 2003).

One complete carapace figured Pl. 1, fig. 6; collection number P6M1439.

Material. Ninety three complete carapaces and fragments.

Type locality. Sample 00A0107, Khuff Formation, Southern

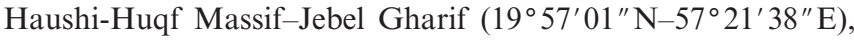
Middle Permian (Wordian).

Distribution. Khuff Formation (samples 00AO102, 00AO106, 00AO107, see Table 1), Jebel Gharif, Central Oman, Middle Permian (Wordian).

Description. RV overlapping the LV all around the carapace except at the cardinal angles; dorsal border straight to gently concave at the RV, straight to gently convex at the left one; cardinal angles obtuse and clear; posterior cardinal angle prolonged by a dorso-posterior border concave at the LV and convex at the RV; posterior border largely rounded and flattened laterally, with the maximum convexity located at the upper third of the height; ventral border straight to gently concave at the RV, straight to convex at the LV; maximum of height located between the anterior third and mid-length; anterior border largely rounded, flattened laterally with the maximum convexity located below mid-height; $S_{2}$ as oval pit with its lower part located just below mid-height; no marginal structure; dorsal view biconvex, with the maximum thickness located at posterior third of length; hinge strongly invaginated terminated by anterior and posterior cardinal teeth; surface 


\begin{tabular}{|c|c|c|c|c|c|c|c|c|c|c|c|c|c|c|c|c|c|}
\hline Sample & 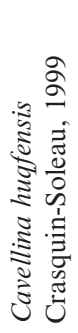 & 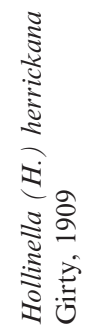 & 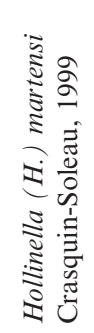 & 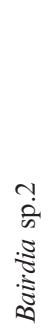 & 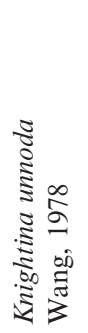 & 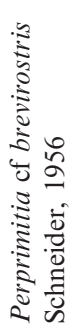 & 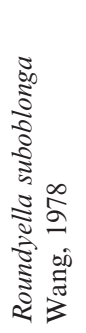 & 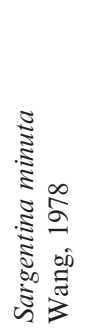 & 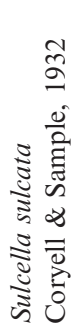 & 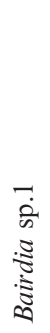 & 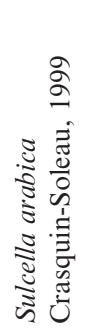 & 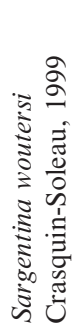 & 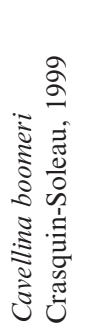 & 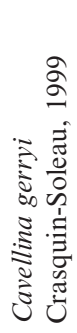 & 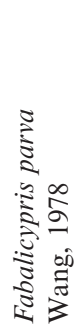 & 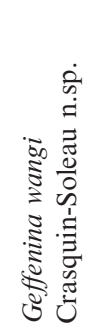 & 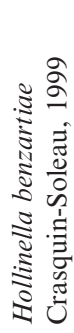 \\
\hline 00AO102 & & XXX & XXXX & & & & & & & & & & $\mathbf{X}$ & & & $\mathbf{X}$ & $\mathbf{X}$ \\
\hline 00AO103 & & $\mathbf{X}$ & $\mathbf{X}$ & & & & & & & & & & & & & & \\
\hline 00AO104 & & $\mathbf{X}$ & $\mathbf{X}$ & & & & & & & & & & $\mathbf{X X X}$ & $\mathbf{X}$ & $\mathbf{X}$ & & \\
\hline 00AO105 & & $\mathbf{X X}$ & & & & & & & & & & & & & & & \\
\hline 00AO106 & & XXX & & & & & & & & & & $\mathbf{X}$ & & & & $\mathbf{X}$ & \\
\hline 00AO107 & & $\mathbf{X}$ & $\mathbf{X}$ & & & & & $\mathbf{X}$ & $\mathbf{X}$ & $\mathbf{X}$ & $\mathbf{X}$ & & & $\mathbf{X}$ & $\mathbf{X}$ & XXXX & \\
\hline
\end{tabular}

XXXX: very abundant (>70 specimens).

XXX: abundant (30 to 70 specimens).

$\mathrm{XX}$ : present (5 to 30 specimens).

$\mathrm{X}$ : rare ( 1 to 5 specimens).

Table 1. Distribution of ostracod species in the Jebel Gharif section.

pitted and reticulated; the pits are relatively large and the layout seems to be random; the reticulation is very fine and is organized parallel to the free margins.

Size. $\quad$ Length $=0.66-1.01 \mathrm{~mm} ; \quad$ height $=0.41-0.59 \mathrm{~mm}$; thickness $=0.42-0.56 \mathrm{~mm}$.

\section{Remarks.}

Presence of a sexual dimorphism (usual in this family). Heteromorphs (female, Pl. 1, fig. 4) have a carapace almost rectangular with a posterior part thicker and higher; tecnomorph (male and larva) have a carapace less high in the posterior part (Pl. 1, figs 1-3, 5-6). This species is attributed to the genus Geffenina as per the revision of the superfamily by Lethiers (1981): $\mathrm{L}_{2}$ clear, no crest, no spine, hinge strongly invaginated, no adventral structure. Geffenina wangi n.sp. seems to be closely comparable to the species Knoxiella oblonga Wang, 1978 from the Late Permian of South China. But the figuration is not very clear and the description is in Chinese. It is also close to the unspined morphotypes of Knoxites aspinifera (Green, 1963) from the Early Carboniferous of the Canadian Rocky Mountains (Green, 1963; Crasquin-Soleau et al., 1993). This last species differs from the new species by the ornamentation and the lack of a spine on $\mathrm{L}_{3}$. Geffenina wangi n.sp. is associated with other ostracods (see Pl. 2) as identified in Table 1.

\section{ACKNOWLEDGEMENTS}

The field expeditions were supported by the international PeriTethys Programme. The author is very grateful to the anonymous reviewer who greatly improved the manuscript.

\section{Manuscript received 22 April 2002 Manuscript accepted 26 February 2003}

\section{REFERENCES}

Angiolini, L. \& Bucher, H. 1999. Guadalupian brachiopods from the Khuff Formation, Southeastern Oman. Geobios, 32: 665-699.

Angiolini, L., Nicora, A., Bucher, H., Vachard, D., Pillevuit, A., Platel, J. P., Roger, J., Baud, A., Broutin, J., Al-Hashmi, H. \& Marcoux, J. 1998. Evidence of a Guadalupian age for Khuff Formation of South-eastern Oman: preliminary report. Rivista Italiana Paleontologia e Stratigrafia, 104(3): 329-340.

Angiolini, L., Balini, M., Garzanti, E., Nicora, A., Tintori, A., Crasquin, S. \& Muttoni, G. 2003. Permian climatic and palaeogeographic changes in the Northern Gondwana: the Khuff Formation of Interior Oman. Palaeogeography, Palaeoclimatology, Palaeoecology, 191: 269-300.

Broutin, J., Roger, J., Platel, J.-P., Angiolini, L., Baud, A., Bucher, H., Marcoux, J. \& Al-Hashmi, H. 1995. The Permian Pangea. Phytogeographic implications of new palaeontological discoveries in Oman (Arabian Peninsula). Comptes Rendus Académie Sciences Paris, 32: 1069-1086.

Crasquin-Soleau, S., Broutin, J., Roger, J., Platel, J.-P., Angiolini, L., Baud, A., Bucher, H., Al Hasmi, A. \& Marcoux, J. 1999. First ostracode fauna from the Upper Permian of Oman (Khuff Formation). Micropaleontology (NY), 45(2): 163-182.

Crasquin-Soleau, S., De Wever, P. \& Renard, M. 1993. Forme et environnement: étude de cas; application un Ostracode paléozoïque. Geobios, Lyon, 26(4): 413-425.

Green, R. 1963. Lower Mississippian Ostracodes from the Banff Formation, Alberta. Research Council of Alberta, 11: 237.

Lethiers, F. 1981. Ostracodes du Dévonien terminal de l'Ouest du Canada: systématique, biostratigraphie et paléoécologie. Geobios, mem sp, 5: 234.

Lethiers, F. \& Crasquin-Soleau, S. 1988. Comment extraire des microfossiles à tests calcitiques de roches calcaires dures. Revue de Micropaléontologie, 31(1): 56-61.

Platel, J.-P., Philip, J., Bourdillon de Grissac, C., Babinot, J.-F., Roger, J. \& Mercadier, C. 1994. Modalités de la transgression campanienne sur le massif du Haushi-Huqf (Oman). Stratigraphie, contexte géodynamique et paléoenvironnements. Bulletin de la Société Géologique de France, 165(2): 147-161.

Wang, S.-q. 1978. Late Permian and Early Triassic ostracodes of Western Guizhou and Northeastern Yunnan. Acta Palaeontologica Sinica, 17(3): 277-312 (in Chinese). 


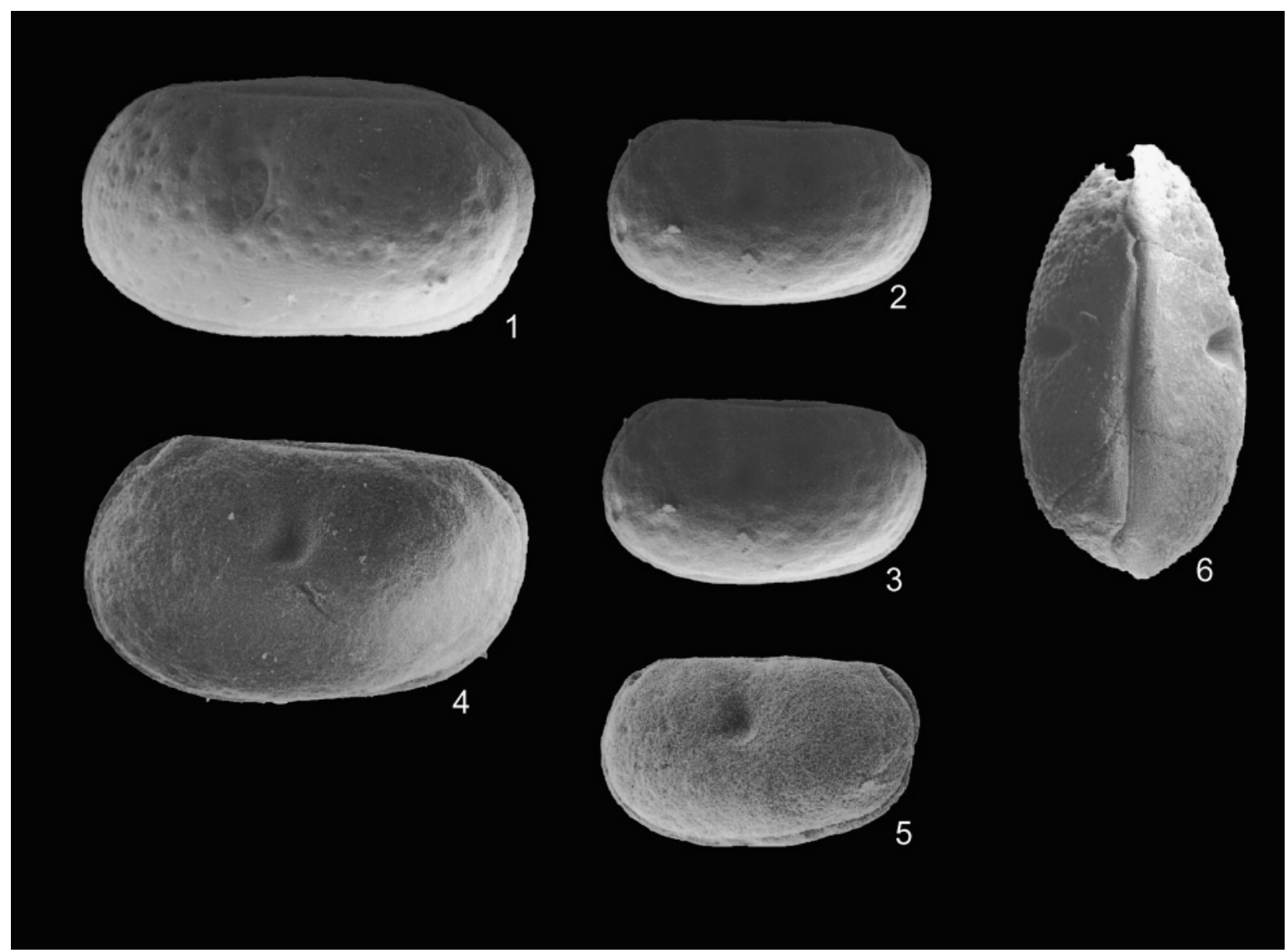

Explanation of Plate 1.

figs 1-6: Geffenina wangi Crasquin-Soleau n.sp. All specimens from sample 00AO107: 1, holotype; left lateral view; heteromorph; P6M1438; $\times 55$; 2, left lateral view; tecnomorph; P6M1440; $\times 55 ; 3$, left lateral view; tecnomorph; P6M1436; $\times 55 ; 4$, paratype; left lateral view; tecnomorph; P6M1435; $\times 80 ;$ 5, left lateral view; tecnomorph; P6M1437; $\times$ 55; 6, paratype; dorsal view; tecnomorph; P6M1439; $\times 55$. All the figured specimens are deposited in the collection of the Laboratoire de Micropaléontologie, Université Pierre et Marie Curie, Paris, France (numbers P6M). All specimens from the Khuff Formation, Jebel Gharif area, Sultanate of Oman. 


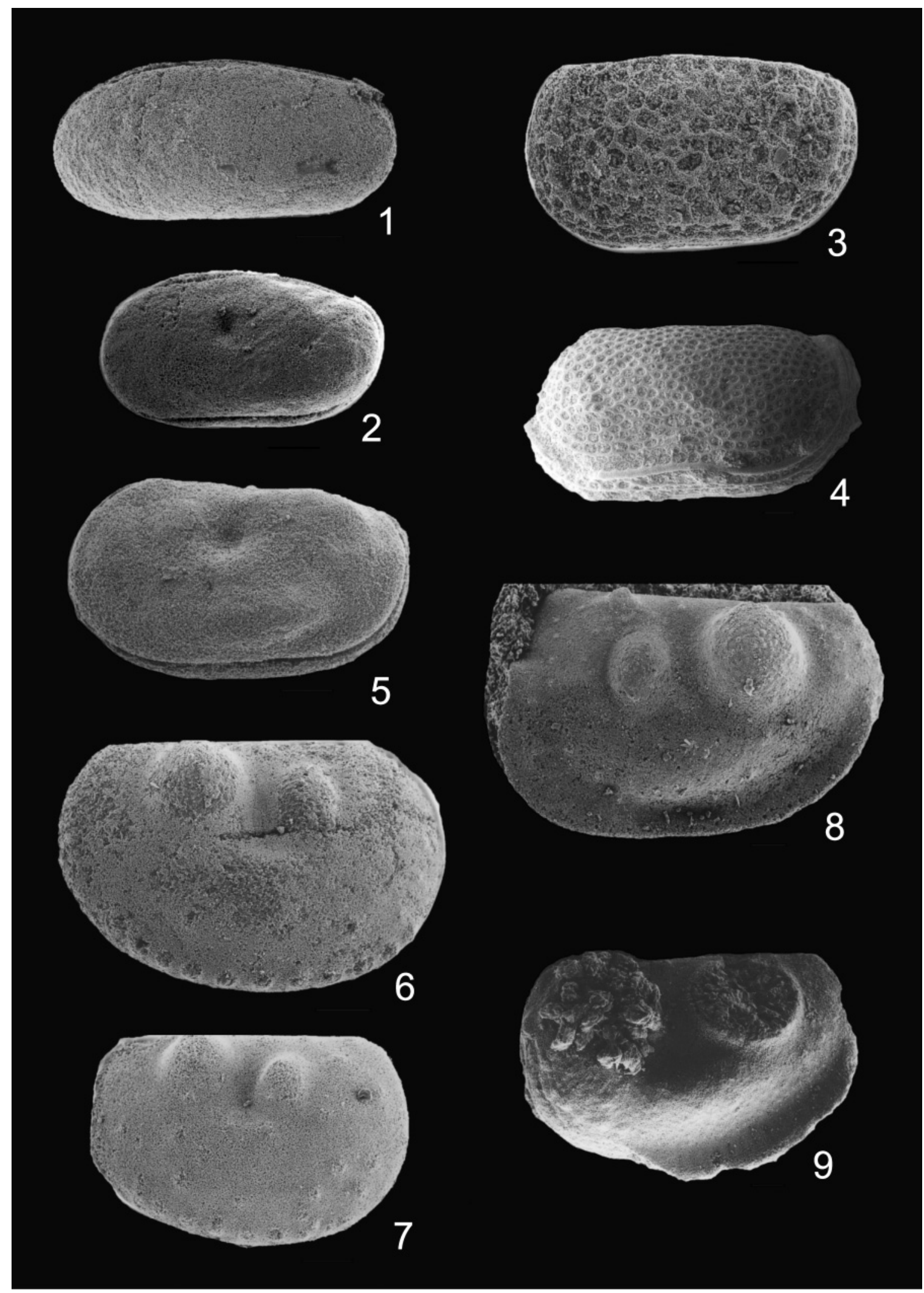

Explanation of Plate 2.

1, Fabalicypris parva (Wang, 1978) left lateral view; P6M1450; $\times 80$; sample 00AO107; 2, Sulcella sulcata (Coryell \& Sample, 1932) left lateral view; P6M1448; × 80; sample 00AO113; 3, Roundyella suboblonga (Wang, 1978) left lateral view; P6M1449; × 110; sample 00AO113; 4, Knightina unnoda (Wang, 1978) right lateral view, P6M1441; $\times 55$; sample 00AO113; 5, Perprimitia cf brevirostris (Schneider, 1956) left lateral view; P6M1447; $\times 80$; sample 00AO113. figs 6-7. Hollinella (H.) martensi (Crasquin-Soleau, 1999). All specimens from sample 00AO102: 6, right lateral view; P6M1442; $\times 80$; 7, right lateral view; P6M1444; × 80. figs 8-9 Hollinella $(H$.) herrickana (Girty, 1909). 8, left lateral view; P6M1445; $\times 50 ;$ sample 00AO102. 9, right lateral view; P6M1446; $\times 45$; sample 00AO115. All the figured specimens are deposited in the collection of the Laboratoire de Micropaléontologie, Université Pierre et Marie Curie, Paris, France (numbers P6M). All specimens from the Khuff Formation, Jebel Gharif area, Sultanate of Oman. 